\title{
理学療法のための薬理学
}

\section{III. パーキンソン病および糖尿病治療薬}

\author{
Introduction to Pharmacology for Physical Therapy Treatment: \\ III. Drugs Used in Parkinson's Disease and Diabetes Mellitus
}

\section{鈴木 正彦}

MASAHIKo SUZUKI

Department of Pharmacology, Saitama Medical School: Moroyama, Iruma-gun, Saitama 350-04, Japan. TEL+81-492-76-1157FAX+81-492-76-1585 e-mail: mhsuzuki@saitama-med.ac.jp

Rigakuryoho Kagaku 12(4): 213-218, 1997. Received Oct. 3, 1997.

ABSTRACT: A series of the reviews have described the interactions between pharmacotherapy and physical therapy in the treatment of various diseases. This third part deals with the interaction occurring in the treatment of Parkinson's disease and diabetes mellitus. Therapeutic agents for Parkinson's disease consist of dopamine agonists and anticholinergic agents, and those for diabetes mellitus are composed of insulin preparations and oral agents for diabetes. Effects of these agents and the interactions with physical therapy were described.

Key words: pharmacotherapy, physical therapy, Parkinson's disease, diabetes mellitus

要旨：薬物療法下の患者に理学療法を行うことも多いが, 両療法は独立して作用するのではなく相互に影響 しあう。本講座の3回目として, 治療のために薬物療法と理学療法を併用する例としてパーキンソン病と糖尿 病を取り上げた。パーキンソン病治療薬はドパミン作用薬と抗コリン作用薬に, 糖尿病治療薬はインスリン 製剂と経口糖尿病薬に分類される。これら薬物の効果と理学療法との関わりについて概説した。 キーワード: 薬物療法, 理学療法, パーキンソン病, 糖尿病

埼玉医科大学薬理学教室：埼玉県入間郡毛呂山町毛呂本郷 38 （广 350-04）TEL 0492-76-1157

受付日 1997年10月3日 


\section{I.はじめに}

現代の医療において薬物療法は重要な役割を果たして おり, 従って薬物療法下の患者に理学療法を実施するこ とも多い。両療法は独立して作用するのではなく, 両者 が協力的に働いたり, 逆に有害作用として現れる場合も ある。今回は, 治療のために薬物療法と理学療法を併用 する例としてパーキンソン病と糖尿病を取り上げ, 両療 法の関わりと治療薬について概説する。

\section{II. パーキンソン病治療薬}

1. パーキンソン病とは

パーキンソン病は, 中年以降に発病し年齢とともに 徐々に進行する神経変性疾患である。1817 年, 英国の医 師 J.パーキンソンによって振戦麻瘏として初めて報告さ れ，その後，彼の名前を取ってパーキンソン病と命名さ れた。その発現頻度は人口 10 万人あたり約 100 人前後で あり, 神経変性疾患の中ではアルッハイマー病に次いで 多い。

パーキンソン病の 4 大徴候として, 筋固縮（rigidity）, 無動 (akinesia), 振戦 (tremor), 姿勢反射障害 (postural disability) があり,このうちのいくつかがあることが診 断の必要条件である。脳血管障害, ウイルス性脳炎, 頭 部外傷, マンガンや一酸化炭素中毒, 薬物中毒 (抗精神 病薬), 脳腫瘍などに続発してパーキンソン病類似の病
像を示す一群の疾患があり,これらをパーキンソン症候 群と呼ぶ。

パーキンソン病の主な病変は, 錐体外路系の一部であ る黒質一線条体系での黒質から線条体へ投射するドパミ ン系ニューロンの変性である。そのためドパミンが減少 し, 同神経路の機能が障害される。正常な状態では, 線 条体においてドパミン系が抑制的に，アセチルコリン系 が促進的に作用してバランスをとり不随運動の調節を 行っている，ドパミンが欠そしアセチルコリン系ニュー ロンへの抑制がとれて,アセチルコリン系優位となり パーキンソン病症状が現れると考えられている（図 1)。 パーキンソン病の治療は薬物療法と理学療法を併用し て行われる（表 1)。薬物療法により筋固縮, 無動, 振戦

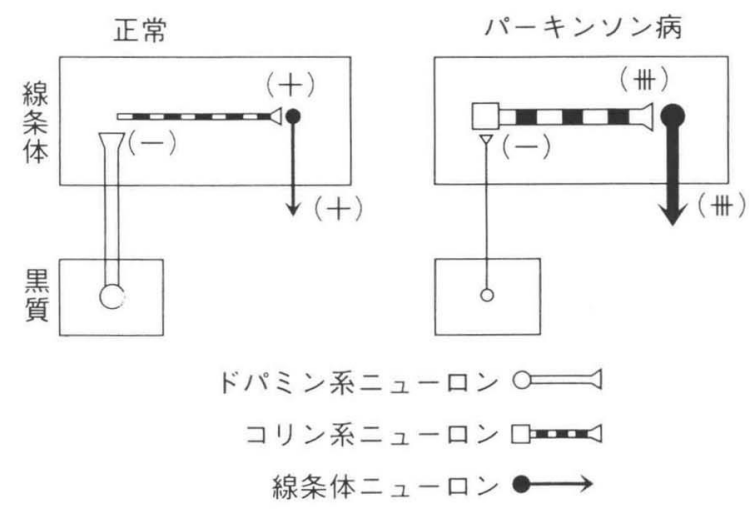

図1 黒質一線条体におけるドパミンおよびアセチルコリン 作動系の相互関係 ${ }^{81}$

表 1 パーキンソン病治療の概要 1)

\begin{tabular}{|c|c|c|c|}
\hline 重症度 & 特 徵 & 薬物療法 & 理学療法 \\
\hline 初期 & $\begin{array}{l}\text { 運動機能は正常 } \\
\text { 一側性の振戦, 固縮 } \\
\text { 日常生活, 通院に介助不要 }\end{array}$ & $\begin{array}{l}\text { トリヘキシフェニジール(振戦に対して) } \\
\text { アマンタジン (無動に対して) }\end{array}$ & 予防的運動プログラム \\
\hline 中期前半 & $\begin{array}{l}\text { 両側性無動, 固縮 } \\
\text { 軽度発語障害 } \\
\text { 前屈姿勢 } \\
\text { 歩行障害 }\end{array}$ & $\begin{array}{l}\text { レボドパ } \\
\text { レボドパ+末梢性脱炭酸酵素阻害薬 }\end{array}$ & 矯正運動プログラム \\
\hline 中期後半 & $\begin{array}{l}\text { 全ての症状が悪化 } \\
\text { 立位, 独歩可能だが生活能力低下 } \\
\text { 日常生活, 通院に介助必要 }\end{array}$ & $\begin{array}{l}\text { レボドパ } \\
\text { レボドパ+末梢性脱炭酸酵素阻害薬 } \\
\text { アマンタジン, ブロモクリプチン }\end{array}$ & $\begin{array}{l}\text { 代償性および矯正運動 } \\
\text { 発語療法 } \\
\text { 作業療法 }\end{array}$ \\
\hline 晚期 & $\begin{array}{l}\text { 極度に日常生活が障害される } \\
\text { 独歩歩行, 起立不能 } \\
\text { 車椅子使用または臥床 }\end{array}$ & $\begin{array}{l}\text { レボドパ } \\
\text { レボドパ+末梢性脱炭酸酵素阻害薬 } \\
\text { ブロモクリプチン, ペリゴリド } \\
\text { アマンタジン, デプレニル } \\
\text { ドロキシドバ }\end{array}$ & $\begin{array}{l}\text { 代償性運動 } \\
\text { スキンケア }\end{array}$ \\
\hline
\end{tabular}


などの症状が改善され，理学療法により筋固縮や姿勢異 常などにより二次的に現れる筋の拘縮や変形が予防さ れ，また，運動障害が改善される。薬物治療が十分な効 果を挙げられなかった場合に外科療法（定位脳手術）を 行う場合もある。

\section{2. パーキンソン病治療薬}

治療薬としては, 減少したドパミン系の機能を増加さ せるドパミン作用薬と六進したコリン系の活動を遮断す る抗コリン作用薬が使用される。

1）ドパミン作用薬

a)レボドパ〔L-ドーパ〕（ドパストン）

ドパミンを補充する目的でレボドパを使用する。ドパ ミンは血液一脳関門を通過しないため，静脈注射や経口 投与しても脳内に到達しない。ドパミンの前駆物質であ るレボドパは血液一脳関門を容易に通過し, 脳内の L-ア ミノ酸デカルボキシラーゼにより脱炭酸されてドパミン に変化して効果を現す。

経口投与されたレボドパの $10 \sim 20 \%$ が小腸から吸収 され全身循環に入り，その95\%は末梢にある L- アミ， 酸デカルボキシラーゼにより脱炭酸されてドパミンに変 化する。そのため脳循環に入るレボドパは経口投与され た1\%以下になってしまい, 線条体で不足したドパミン を補充するためには大量のレボドパを内服する必要があ る。そこで末梢においてこの酵素を阻害するカルビドパ やベンセラジドが開発された。これらを末梢性 L-アミノ 酸デカルボキシラーゼ阻害薬 (DCI) と呼ぶ。カルビドパ およびベンセラジドを併用するとレボドパの使用量を， それぞれ $1 / 10$ および $1 / 4$ に減量することができる。ま た，併用により末梢性副作用 (悪心，嘔吐，不整脈）も軽 減される。現在はレボドパ・カルビドパ（ネオドパスト ン), レボドパ・ベンセラジド（ネオドパゾール）のよう な合剂が製造されている。レボドパは無動や筋固縮に有 効であるが，振戦に対する効果は弱い。また，日常動作 や歩行障害は著明に改善する。

副作用として以下のものがある。

消化器症状：悪心，嘔吐，食思不振などの症状が 40 80\%の患者にみられる。これは，嘔吐中枢刺激作用による。

循環症状：約 $30 \%$ の患者に起立性低血圧が発現する。 ただし，この症状は数週間で耐性を生じることが多い。

精神症状:5 10\%の患者で興奮，不穏，不眠がみられる。 神経症状：レボドパの長期投与により 20 ～60\%の患者 で異常不随運動（ドーパ誘発性ジスキネジア）がみられ る。加えて，レボドパの有効時間の短縮（wearing off 効 果), レボドパの服薬一定時間後, 突然薬効が無くなり症
状が増悪する on and off 現象，症状の改善と増悪に日内 変動が起きる up and down 現象が現れる。これらの症状 が現れた場合は，レボドパを減量しブロモクリプチンな どを使用する。

b) アマンタジン (シンメトレル)

当初は $\mathrm{A}_{2}$ 型インフルエンザに尒防効果のある抗ウイ ルス薬として開発されたが,パーキンソン病の症状を改 善することが分り，臨床応用されようになった。わが国 ではパーキンソン病だけの適応が認められている。

アマンタジンの主な作用は, 線条体におけるドパミン 系ニューロン終末からドパミン遊離を促進することであ る。治療効果はレボドパより弱いが, 抗コリン作用薬よ り強い。筋固縮, 無動, 姿勢障害に有効であり, 振戦に対 する効果はやや劣る。速効性で，振戦のない初期患者に 単独で使用される。また，アマンタジンはジスキネジア を生じにくいのでレボドパでジスキネジアが現れた時に は,レボドパを減量しアマンタジンを併用する。副作用 はレボドパや抗コリン作用薬に比べ少ない。

c) ブロモクリプチン (パーロデル)

血液一脳関門を通過し, 線条体のドパミン受容体を直 接刺激する作用薬である。作用時間はレボドパよりはる かに長い。副作用として悪心，嘔吐が現れるが，これら は耐性を生じる。

\section{2) 抗コリン作用薬}

異常圥進しているアセチルコリン系の機能を抑制し, ドパミン系とのバランスを保つ。

レボドパによるドパミン補充療法が確立する以前は, 専ら抗コリン薬が治療に使用された。重症パーキンソン 症候群にはレボドパなどのドパミン作用薬が著効を示す ので，抗コリン作用薬は補助的な役割になった。しかし ながら, 初期治療, 軽症パーキンソン病には現在も広く 使用されている。

以前はアトロピンやスコポラミンなどが使用されたが 副交感神経遮断による副作用や精神症状が強いため，現 在はトリヘキシフェニジル（アーテン）などが使用され ている。また, 抗ヒスタミン薬のうち抗コリン作用の強 いジフェンヒドラミンも使用される。

振戦や筋固縮に有効であるが無動に対する効果は弱 い。副作用として副交感神経遮断症状（かすみ目, 散瞳, 緑内障の悪化，尿閉，胃腸運動障害）および精神症状 (幻 覚，錯乱）、ジスキネジアがある。

3)その他

a)ドロキシドパ(ドプス)

L-アミノ酸デカルボキシラーゼで脱炭酸されノルア ドレナリンに変換される合成の前駆物質である。パーキ 
ンソン病の脳では, ドパミンに加えノルアドレナリンの 欠乏もあり，錐体外路症状，うつ状態，自律神経症状の 一因と考えられている。経口投与されたドロキシドパは, 脳内へ移行しノルエピネフリンを補充する。末梢性 L-P ミノ酸デカルボキシラーゼ阻害薬との併用により, 投与 量，末梢性副作用を軽減できる。

ドロキシドパは，パーキンソン病の晚期にみられるす くみ現象や意欲低下, 起立性低血圧などに著効を示す。

b) $\mathrm{MAO}_{\mathrm{B}}$ 阻害薬

モノアミンを分解するモノアミンオキシダーゼ （MAO）には A と B の二種類があり, A 型はノルエピネ フリンやセロトニン, B 型はドパミンやチラミンを分解 する。 $\mathrm{MAO}_{\mathrm{B}}$ 阻害薬を使用すると線条体のドパミンシナ プス間隙でのドパミン濃度が上昇し, ドパミン神経系を 賦活させる。代表薬としてデプレニルがあり, 現在わが 国では臨床試験中である。

\section{III. 糖尿病治療薬}

\section{1. 糖尿病とは}

糖尿病は,インスリン作用の不足にもとづいて糖代 謝, 脂質代謝, 蛋白代謝の変動が持続する疾患であり, 耐 糖の低下・慢性の高血糖を特徴とする。䍦患期間が長く なると, しばしば特有の合併症 (網膜症, 腎症, ニューロ パチーなど）が現れ，また動脈硬化が促進される。

糖尿病は, 大きくインスリン依存性糖尿病 (IDDM) と インスリン非依存性糖尿病（NIDDM）に分けられる（表
2)。IDDM は㬸臓の B 細胞の病変によりインスリンが絶 対的に不足することに起因し，NIDDM はインスリン分 泌能は残っているもののインスリン必要量の増大に対す る相対的不足によって生じる。わが国での糖尿病の有病 率は 40 歳以上の成人の $10 \%$ に達し, 糖尿患者は 500 600万人になると推定されおり，そのほとんどがNIDDM で, IDDM は約 75,000 人とされる。

治療の基本は, (1)食事療法, (2)運動療法, (3)薬物療法 の三つであり，IDDM やインスリン療法が適応となる NIDDM などの場合を除いて, まず食事療法と運動療法 で治療を開始する。

運動療法は，インスリン感受性改善を介して耐糖の悪 化を予防し，糖尿病における糖代謝異常を是正する。ま た，運動療法は，糖尿病患者にしばしば合併する軽度の 高血圧や高脂血症の改善といった糖尿病血管合併症のリ スクファクターも軽減する（表 3 )。一方で, 糖尿病患者 に理学療法を施す場合は, 糖尿病患者が正常人に比べ, 狭心症, 心筋梗塞, 腎不全, 失明などを有している場合 が多いことから注意が必要である。

\section{2. 糖尿病治療薬}

1)インスリン

IDDM および NIDDM で食事療法, 運動療法, 経口桾 尿病薬によって良好な血糖コントロールが得られない場 合などに使用される。

インスリンは(1)筋肉, 脂肪組織で糖の取り込みを促進 L, (2)脂肪組織で脂肪分解を抑制し，(3)筋肉，肝臓でグ

表 2 インスリン依存型糖尿病とインスリン非依存型糖尿病の比較 ${ }^{81}$

\begin{tabular}{|c|c|c|}
\hline & インスリン依存型 & インスリン非依存型 \\
\hline 原 因 & $\begin{array}{l}\text { 1) ウイルス感染 } \\
\text { 2) 自己凭疫異常 }\end{array}$ & 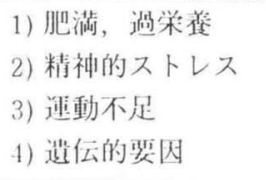 \\
\hline 発症作歳命 & 20藏以下に多い & 40战以上に多い \\
\hline 糖原病全作に対する比率 & $5 \%$ 以下 & $95 \%$ 以上 \\
\hline 症状の発現 & 急性および悪急性 & 緩徐 \\
\hline 代謝性アシドーシスの発現 & しばしば & まれ \\
\hline 体 格 & やせ型が多い & 肥満型が多い \\
\hline 血中インスリン値 & 減少 & 一定しない \\
\hline 治療法 & $\begin{array}{l}\text { 1) インスリン注射 } \\
\text { 2) 食事療法 }\end{array}$ & $\begin{array}{l}\text { 1) 食事, 運動療法 } \\
\text { 2) 経口糖尿病薬 } \\
\text { 3) インスリンン注射 }\end{array}$ \\
\hline
\end{tabular}


リコーゲン，蛋白の合成を促進する作用がある。

インスリン製剂には多くの種類があり，作用発現時間 と持続時間の違いで速効型, 準速効型, 中間型, 持続型 に分類される（表4）。また, インスリンはポリペプチド 構造を有するため内服では胃酸で分解されるため, 通常, 皮下または筋肉内注射される。ただし，速効型インスリ ンを静脈内注射や筋肉内注射する場合もある。

皮下注射されたインスリンの吸収が理学療法で以下の 様に影響される可能性がある。

(1)投与部位の加温により局所血量が増加しインスリン の吸収が促進される，(2)逆に投与局所の冷却により吸収 が抑制される，(3)投与部位を動かす運動により吸収が促 進される, (4)投与部位のマッサージにより吸収が促進さ れるなどである。

2) 経口糖尿病薬

a) スルフォニル尿素系薬物

抗菌薬のサルファ剂に低血糖を起こす性質のものがあ り，膵臓を摘出した動物ではその性質が見られないとう ことをヒントに作られた薬物である。トルブタミド（ラ
スチノン), クロルプロパミド(ダイヤビニーズ), アセ トヘキサミド (ジメリン), グリベンクラミド (オイグル コン）などがある。

これら薬物は，ランゲルハンス島B細胞にある ATP 依 存性 $\mathrm{K}^{+}$チャンネルを抑制することにより B 細胞を脱分 極して, 電位依存性 $\mathrm{Ca}^{2+}$ チンネルを開き, 細胞内 $\mathrm{Ca}^{2+}$ イオンを上昇する。その結果, 内因性インスリン分泌が 促進される。従って, B 細胞にインスリン分泌能が残っ ていない場合は無効である。

NIDDM で, 食事療法, 運動療法がある程度守られて 3ヶ月以上経過しているにもかかわらず改善が認められ ない場合に使用する。

b) $\alpha$-グルコシダーゼ阻害薬

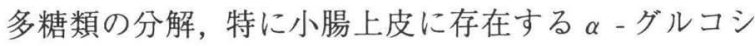
ダーゼの作用を阻害して, 単糖類 (ブドウ糖, 果糖)への 分解を抑制することにより，食後の急激な血糖上昇を抑 える。食後血糖值の高い例が良い適応となる。アカルボー ス (グルコバイ), ボグリボース (ベイスン) などがある。

表 3 糖尿病患者における運動療法の効果 ${ }^{4}$

1）コントロール良好例血糖值低下, インスリン拮抗ホルモン過剩反応の是正

急性効果 2）コントロール不良例血糖值の上昇, ケトン体·遊離脂肪酸の増加

インスリン拮抗ホルモン過剩反応

1) 耐糖能の改善

2)インスリン感受性の改善

慢性効果

3）脂質代謝改善

中性脂肪の低下, LDL-コレステロールの低下

HDL- コレステロールの増加

4) 肥満改善

5）骨量減少防止

6) 心肺機能の改善

7）ストレス解消効果など

表 4 インスリン注射製剂の種類と特徴 ${ }^{8)}$

\begin{tabular}{|c|c|c|c|c|c|}
\hline タイプ & 製 剂 & 外観 & 作用発現 & 持続時間 & その他 \\
\hline \multirow[t]{2}{*}{ 速効型 } & レギュラーインスリン & 透明 & $0.5 \sim 1 \mathrm{~h}$ & $3 \sim 8 \mathrm{~h}$ & \\
\hline & アクトラピッドインスリン & 透明 & $0.5 \mathrm{~h}$ & $8 \mathrm{~h}$ & \\
\hline 準速効型 & セミレンテインスリン & 懸濁 & $1.5 \mathrm{~h}$ & $16 \mathrm{~h}$ & \\
\hline \multirow[t]{2}{*}{ 中間型 } & レンテインスリン & 奬濁 & $2.5 \mathrm{~h}$ & $24 \mathrm{~h}$ & \\
\hline & $\begin{array}{l}\text { NPH インスリン（イソフェ } \\
\text { ンインスリン） }\end{array}$ & 矁濁 & $1 \sim 1.5 \mathrm{~h}$ & $18 \sim 24 \mathrm{~h}$ & セミレンテ＋ウルトラレンテ（3：7） \\
\hline 2 相性 & ラピタードインスリン & 奬濁 & $0.5 \mathrm{~h}$ & $24 \mathrm{~h}$ & アクトラピッド+ウルトラレンテ（1：3） \\
\hline \multirow[t]{2}{*}{ 持続型 } & ウルトラレンテインスリン & 奬濁 & $4 \mathrm{~h}$ & $36 \mathrm{~h}$ & \\
\hline & プロタミン亜鉛インスリン & 軞濁 & $4 \sim 8 \mathrm{~h}$ & $36 \mathrm{~h}$ & \\
\hline
\end{tabular}




\section{引用および参考文献}

1) Custon TM, et al.: Pharmacological and nonpharmacological intervention in the treatment of Parkinson's disease. Phys Ther, 75: 363-373, 1995.

2) Betts EF, et al.: Pharmacologic management of hyperglycemia in diabetes mellitus: Implication for physical therapy. Phys Ther, 75: 415-425, 1995.

3) 小川紀雄・編: 神経内科治療ガイド, 中外医学社, 東京, 1991.
4) 阿部正和・他監: 糖尿病一外来診療のポイント, 日本医師会, 東京, 1990

5) 日野原重明·他監:今日の治療指針 1997版, 医学書院, 東京, 1997.

6) 田中千賀子·他編：NEW 薬理学第3 版, 南江堂, 東京, 1996 7) 海老原昭夫·監: 標準薬理学第 5 版, 医学書院, 東京, 1997.

8) 鈴木正彦:薬理学 (メデイサイトクイックマスターブック), 医学芸術社, 東京, 1996 